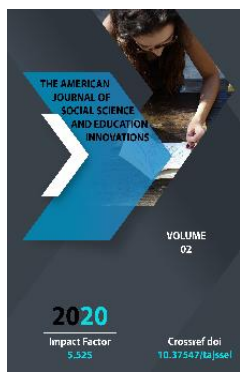

Copyright: Original content from this work may be used under the terms of the creative commons attributes 4.0 licence.

\section{The Use Of Local Vegetable Raw Materials In The Production Of Soft Drinks}

\author{
G. T. Zaripov \\ Lecturers Of Bukhara State University, Uzbekistan \\ S. M. Nazarova \\ Lecturers Of Bukhara State University, Uzbekistan
}

\title{
ABSTRACT
}

In recent years, the Uzbek market has noticeably replenished with non-alcoholic beverages prepared on the basis of imported extracts. In the technology of preparation of which sweeteners, dyes, flavors and similar components of unnatural origin were increasingly used. Without disputing the nutritional merit of these components, it is nevertheless necessary to give preference to drinks prepared on the basis of natural ingredients.

\section{KEYWORDS}

Drink, beverage technology, vegetables, raw materials, components

\section{INTRODUCTION}

Development of beverage technologies based on local non-traditional environmentally friendly raw materials also remains an urgent problem. As such, we suggest using red carrots and Spanish pumpkin varieties. According to the literature [1], red carrots and pumpkin have the following chemical composition (see table 1). 
MATERIALS AND METHODS

The chemical composition of red carrots and pumpkin

(in g. per $100 \mathrm{~g}$ of edible part)

Table 1

\begin{tabular}{|c|c|c|c|c|c|c|c|}
\hline № & $\begin{array}{l}\text { Component } \\
\text { name }\end{array}$ & $\begin{array}{l}\text { Red } \\
\text { carrot }\end{array}$ & Pumpkin & № & $\begin{array}{l}\text { Component } \\
\text { name }\end{array}$ & $\begin{array}{l}\text { Red } \\
\text { carrot }\end{array}$ & Pumpkin \\
\hline 1. & Water & 88,5 & 86,2 & 11. & $\mathrm{Ca}, \mathrm{mg}$ & 51 & 40 \\
\hline 2. & Protein & 1,3 & 1,0 & 12. & $\mathrm{Mg}, \mathrm{mg}$ & 38 & 14,0 \\
\hline 3. & Fats & 0,1 & - & 13. & P, mg & 55 & 25,5 \\
\hline 4. & $\begin{array}{l}\text { Carbohydrates, } \\
\text { incl. mono- and } \\
\text { disaccharides, } \\
\text { starch, etc. }\end{array}$ & $\begin{array}{l}7,8 \\
6,0 \\
0,2 \\
0,6\end{array}$ & $\begin{array}{l}\text { IV,o } \\
2,0 \\
0,4\end{array}$ & $\begin{array}{l}14 . \\
15 .\end{array}$ & $\begin{array}{l}\text { Fe, mg } \\
\text { Vitamins (mg / } \\
\text { kg) } \\
\beta \text { carotene B1 }\end{array}$ & \begin{tabular}{|l|}
1,2 \\
0,07 \\
9,00 \\
0,06
\end{tabular} & $\begin{array}{l}0,8 \\
0,03 \\
1,50 \\
0,05\end{array}$ \\
\hline 5 . & Cellulose & 2,2 & 2,4 & & & & \\
\hline 6. & Org. acid & 0,1 & 0,1 & 16. & B6 & 0,07 & 0,03 \\
\hline 7. & Mineral stuff & & & 17. & & & \\
\hline 8. & Ash & 1,0 & 0,6 & 18. & P P & 1,00 & 0,50 \\
\hline 9. & $\mathrm{Na}, \mathrm{mg}$ & 21 & 14 & 19. & $C$ & 5 & 8 \\
\hline 10. & $\mathrm{~K}, \mathrm{mg}$ & 200 & 170 & & $\begin{array}{l}\text { Energy value, } \\
\text { QOL }\end{array}$ & 138 & 121 \\
\hline
\end{tabular}

As you can see from the table, the pulp of red carrots and pumpkin is very rich in biologically active substances. We set a goal: to extract as much as possible the useful components of carrots and pumpkin into the extract and, on its basis, prepare a soft drink.
The extraction of useful components of vegetables was carried out with a solution of citric acid of various concentrations at a temperature in the range from 60 to $900 \mathrm{C}$ for 3 to 30 minutes. The extraction effect was established refractometrically by the maximum extraction of dry substances. It was found that the greatest effect of extraction is 
obtained when using a $0.5 \%$ citric acid solution; the optimal parameters for the process were: temperature - $70 \mathrm{C}$, duration - 7 minutes. Concentration of the extract was carried out in a vacuum at $700 \mathrm{C}$ until the accumulation of dry matter up to $55 \%$.

\section{RESULTS AND DISCUSSIONS}

It was interesting to study the activity of the enzymes beta-fructofuranosidase and exterase (hydrolyzing function) in concentrated extracts obtained using citric Dependence of the activity of beta-fructo-furanosidase enzymes and esterases in concentrates from acid concentration

Table 2

\begin{tabular}{|c|c|c|c|}
\hline № & $\begin{array}{c}\text { The concentration of citric } \\
\text { acid in the extract }\end{array}$ & $\begin{array}{c}\text { The activity of beta-fructo } \\
\text { Furanosidase }\end{array}$ & Esterase Activity \\
\hline 1 & 0,15 & 3,4 & 0,65 \\
\hline 2 & 0,25 & 3,9 & 1,30 \\
\hline 3 & 0,35 & 7,7 & 1,67 \\
\hline 4 & 0,45 & 8,5 & 2,37 \\
\hline 5 & 0,55 & 9,9 & 5,9 \\
\hline 6 & 0,65 & 10,5 & 6,35 \\
\hline 7 & 0,75 & 10,5 & 6,35 \\
\hline
\end{tabular}

As can be seen from table 2, the greatest activity of enzymes is observed in samples of concentrates obtained with $0.5-0.7 \%$ aqueous solution of citric acid. It is known that the high activity of the beta-fructofuranosidase enzyme will promote not only the hydrolysis of sucrose in the finished drink, but also the synthesis of various alkylfructosides, which acid solution. The research results are shown in Table 2.

As a ferment-containing object, $1 \mathrm{~g}$ of concentrated extract was used. The betafructofuranosidase activity was expressed in $\mathrm{ml}$. $0.1 \mathrm{~N}$ potassium permanganate solution used for titration in the determination of invert sugar according to Bertrand in the object during incubation for 2 hours. Esterase activity was expressed in ml. 0.1 N NaOH solution used for titration of hydrolyzed ethyl acetate. 
exchange anion exchanger EDE-1010 $P$ in the form of $\mathrm{CO}_{2}$ at a flow rate of $1 \mathrm{ml} / \mathrm{min}$. The acids were eluted with a $10 \%$ solution of ammonium carbonate. Ammonium salts of organic acids were separated on a KU - 2 cation exchanger in the $\mathrm{H}+$ form. A mixture of $\mathrm{n}$-butyl alcohol, formic acid, and water in a ratio of $7: 1$ : 2 was used as a solvent for chromatography. Organic acids were developed with $0.04 \%$ alcohol solution of bromocresol blue.

Comparison of stains with organic acid taps showed that pumpkin-carrot concentrate contains such acids as: malic, succinic, citric, tartaric, glycolic, lactic, 2-unknown. All these acids give the drink a slight freshness.

The production of the Kovsar drink, created on the basis of the obtained raw materials, required the solution of two problems. First: ensuring the homogeneity of the composition of the drink, which does not allow delamination. The second is to ensure a long shelf life of the drink.
By itself, the drink "Kovsar" has a biologically rich composition. Since it is made from pumpkin and red carrots, the valuable components of these plant fruits, such as enzymes, amino acids, monosugar, essential oils, vitamins, etc., have passed into the drink. As well as polypeptides, cellulose, pectin substances, hemicellulose, etc. The latter create a platform on which to hold the pigments, imparting a specific color to the finished product.

During long-term storage, condensation of molecules or the combination of various molecules may occur, forming macromolecules insoluble in syrup. In this case, the components in the drink are stratified. The condensation of molecules and the reaction of their combination largely depends on the $\mathrm{pH}$ of the medium. It is $\mathrm{pH}$ that dictates the charge of various macromolecules. For this purpose, experiments were carried out to measure the stabilization of the Kovsar drink on the basis of varying the $\mathrm{pH}$ of the medium. The $\mathrm{pH}$ of the drink can be changed in two ways.

\section{Change in the $\mathrm{pH}$ of the drink and the duration of separation depending on the concentration of citric acid}

Table 3

\begin{tabular}{|c|c|c|c|c|}
\hline № & $\begin{array}{c}\text { Citric acid } \\
\text { concentration, g/ L }\end{array}$ & $\begin{array}{c}\text { Duration from } \\
\text { the onset of } \\
\text { stratification } \\
\text { in days }\end{array}$ & Taste \\
\hline 1. & 1 & 4 & 7 & Tart \\
\hline 2. & 1,5 & 4 & 9 & Tart \\
\hline 3. & 2,0 & 3,9 & 9 & Tart \\
\hline
\end{tabular}


The American Journal of Social Science and Education Innovations (ISSN - 2689-100x)

Published: October 29, 2020 | Pages: 183-188

Doi: https://doi.org/10.37547/tajssei/Volume02Issue10-30

\begin{tabular}{|c|c|c|c|c|}
\hline 4. & 2,5 & 3,7 & 11 & Neutral \\
\hline 5. & 3,0 & 3, & 15 & Slightly sour. \\
\hline 6. & 3,5 & 3,3 & 19 & Sweet and sour. \\
\hline 7. & 4,0 & 3,1 & 24 & Sweet and sour. \\
\hline 8. & 4,5 & 2,9 & 30 & Sweet and sour. \\
\hline 9. & 5,0 & 2,7 & 30 & Sourish \\
\hline
\end{tabular}

The first way is to change the concentration of citric acid (see table 3 ). The best result was obtained with a citric acid concentration of 4.5 $\mathrm{g} / \mathrm{l}$ and $\mathrm{a} \mathrm{pH}$ of 2.9.

In order to ensure biological stability in all versions of the drink, the same dose of sodium benzonate was set.

\section{CONCLUSION}

We have also carried out work [4] to ensure the homogeneous stability of the drink based on food pectin. The optimal dose of pectin is set at $0.05 \%$. This is enough to ensure homogeneous stability, which is explained by the 25 -fold swelling of pectin in the medium of sugar and organic acid. It is this quality of pectin that makes it possible to increase the viscosity of the drink, hence its homogeneous stability.

\section{REFERENCES}

1. The chemical composition of food. // Edited by A.A. Pokrovsky.-M., Pishchepromizdat, 1976.

2. Abdurazzakova S.Kh., Salomov Kh.T., Babakhanov B.A., Vaisova Z.Sh. Formation of alkylfructosides in wines under the action of beta-fructofuranosidase // Uzbek Biological Journal. - 1978. - No. 6.
3. Zaripov G.T. Technology of preparation of a soft drink based on local plant materials // Problems of intensification of the integration of science and production: Collection of works of International. scientific-practical conf. - Bukhara, 2006 .--S. 301-302.

4. Egamberdiev NB, Salomov Kh.T., Zaripov G.T. Stabilization of soft drinks using cotton pectin // Abstracts of the Republican Scientific and Technical Conference "Scientific and Practical Aspects of Complex Processing of Cotton" .- Tashkent, 1989.

5. Nazarova Sevara Mustakimovna, Gulmurot Taxirovich Zaripov. Granulometric composition irrigated soils of bukhara region. Journal of critical reviews. issn2394-5125 vol 7, issue 17, 2020 /

6. Zaripov G.T. Functional drink "Kavsar" based on vegetable raw materials. Scientific Bulletin of Bukhara State University Bukhara, 2013. - №2. - S.19-22.

7. Atoeva M.F., Safarova R.S. Pedagogical integration as a means of forming professionally important qualities among students of a medical university. ACADEMICIA: An International Multidisciplinary Research Journal. https://saarj.com. ISSN: 2249-7137 Vol. 10, Issue 8, August 2020. P. 562-567. Impact Factor: SJIF $2020=7.13$ 
8. Atoeva M.F. Pedagogical Tests As An Element of Types Of Pedagogical Technologies. The American Journal of Applied Sciences, 2(09), (TAJAS) SJIF-5.276 DOI-10.37547/tajas Volume 2 Issue 9, 19.09.2020. ISSN 2689-09. 92 The USA Journals, USA www.usajournalshub.com/index.php/tajas 164-169. IF.5.2.

9. Atoeva M.F. The problems of preparing students for the use of school physical experiment in the context of specialized education at secondary schools. European Journal of Research and Reflection in Educational Sciences Vol. 8 No. 9, 2020 ISSN 2056-5852. P.164-167.

10. Saidov S.O., Fayzieva Kh. A., Yuldosheva N. B., Atoeva M.F. The Elements Of Organization Of The Educational Process On The Basis Of New Pedagogical Technologies. The American Journal of Applied Sciences, 2(09), (TAJAS) SJIF-5.276 DOI-10.37547/tajas Volume 2 Issue 9, 19.09.2020. ISSN 2689-09. 92 The USA Journals, USA www.usajournalshub.com/index.php/tajas 164-169. Имп.5.2.

11. Atoeva M.F. Frequency of teaching physics. Post-graduate student and applicant. Moscow, 2010. -№6. - S. 41-43.

12. S.S.K. Kaxhorov, Atoeva M.F. Frequency as a pedagogical regularity of teaching physics. Pedagogical sciences. -Moscow, 2010. -№ 6. - P. 56-59.

13. M.F. Atoyeva. Interdisciplinary relations in physics course at specialized secondary education. The Way of Science. - Volgograd, 2016. - No. 9 (31). - P. 22-24.

14. M.F. Atoyeva. The significance of periodicity at teaching physics. The Way of Science. Volgograd, 2016. -№ 10 (32). - P.62-64.

15. Atoeva M.F. The effectiveness of teaching electrodynamics based on the technology of periodicity. The Way of Science. Volgograd, 2016. - No. 10 (32). - P.65-66.

16. M.F. Atoyeva. Use of Periodicity in Teaching Physics. Eastern European Scientific Journal. -Düsseldorf-Germany, 2017. № 4. P. 35-39. 